\title{
Whole body amino acid composition of Indian major carps and its significance
}

\author{
Satyendra N. Mohanty (1) and Sadasivam J. Kaushik \\ (2) \\ (1) Central Institute of Freshwater Aquaculture, Kausalyaganga, Bhubaneszear, 751002 (Orissa), India. \\ (2) INRA, Fish Nutrition Laboratory, Station d'Hydrobiologie, G4310 Saint-Pée-sur-Nivelle, France.
}

Received March 16, I990; accepted September 3, I990.

Composition en acides aminés des carpes indiennes en vue de l'estimation des besoins nutritionnels.

Mohanty S. N., S. J. Kaushik. Aquat. Living Resour., 1991, 4, 61-64.

\section{INTRODUCTION}

Catla (Catla catla), rohu (Labeo rohita) and mrigal (Cirrhinus mrigala) are three Indian major carp species widely cultured in the Indian sub-continent under semi-intensive and intensive polyculture conditions. Currently, only estimates of the gross dietary protein requirements of the three species are available: 40 $45 \%$ protein for rohu, $40 \%$ for mrigal and $47 \%$ for catla (Sen et al., 1978; Singh and Bhanot, 1988; Swamy et al., 1988; Mohanty et al., 1989). Their amino acid requirements are unknown. Information in this regard is of importance for evolving leastcost, nutritionally balanced diets for achieving high production.

The dietary proteins should provide essential amino acids (EAA) in sufficient amounts to meet the EAA needs of a given animal. The EAA profile of dietary proteins should also be similar to that of the requirement profile. In earlier studies on EAA needs of fish, the amino acid patterns of test diets were based on the amino acid profile of the chicken egg protein. As high correlations were found to exist between the amino acid requirements and whole-body amino acid composition in several fishes, it was suggested that such data be used to set the basis for the estimation of the amino acid requirements of fish (Cowey and Tacon, 1983; Wilson and Poe, 1985; Wilson and Cowey, 1985; Gatlin, 1987). Arai (1981) used essential amino acid ratios of the whole body of fish for developing a purified test diet for coho salmon,
Oncorhynchus kisutch. Wilson and Poe (1985) found good correlations between such ratios in the whole body and those of the requirement values of channel catfish (Ictalurus punctatus).

With this background, an attempt is made here to compare data on the whole-body amino acid composition of the three major Indian carp species and to determine their amino acid requirement profiles.

\section{MATERIAL AND METHODS}

Induced bred fry of catla $(0.59 \mathrm{~g})$, rohu $(0.67 \mathrm{~g})$ and mrigal $(0.69 \mathrm{~g})$ reared in experimental ponds (Central Institute of Freshwater Aquaculture, Dhauli, Orissa, India) were used for studies on whole-body amino acid composition. All fishes were grown in the same pond under natural temperature $\left(28-36^{\circ} \mathrm{C}\right)$ and natural photoperiod conditions from the larval stage onwards under semi-intensive conditions. The fry were raised on natural plankton available in the pond supplemented with a feed mixture of $(1: 1)$ groundnut cake and rice bran. After evacuating their gut contents, triplicate composite samples were prepared by taking thirty whole fish from each lot and oven dried (AOAC, 1975) as the lyophilisation of samples was not possible. The resulting dried samples were finely powdered, seived and analysed for protein (AOAC, 1975) and amino acid composition after vacuum hydrolysis of the samples in $2 \mathrm{ml}$ of $6 \mathrm{~N} \mathrm{HCl}$ at 
Table 1. - Amino acid composition of whole body tissue of catla, rohu and mrigal fry compared with that of common carp and with that of conventional feed mixture (groundnut oil cake and rice bran, 1:1).

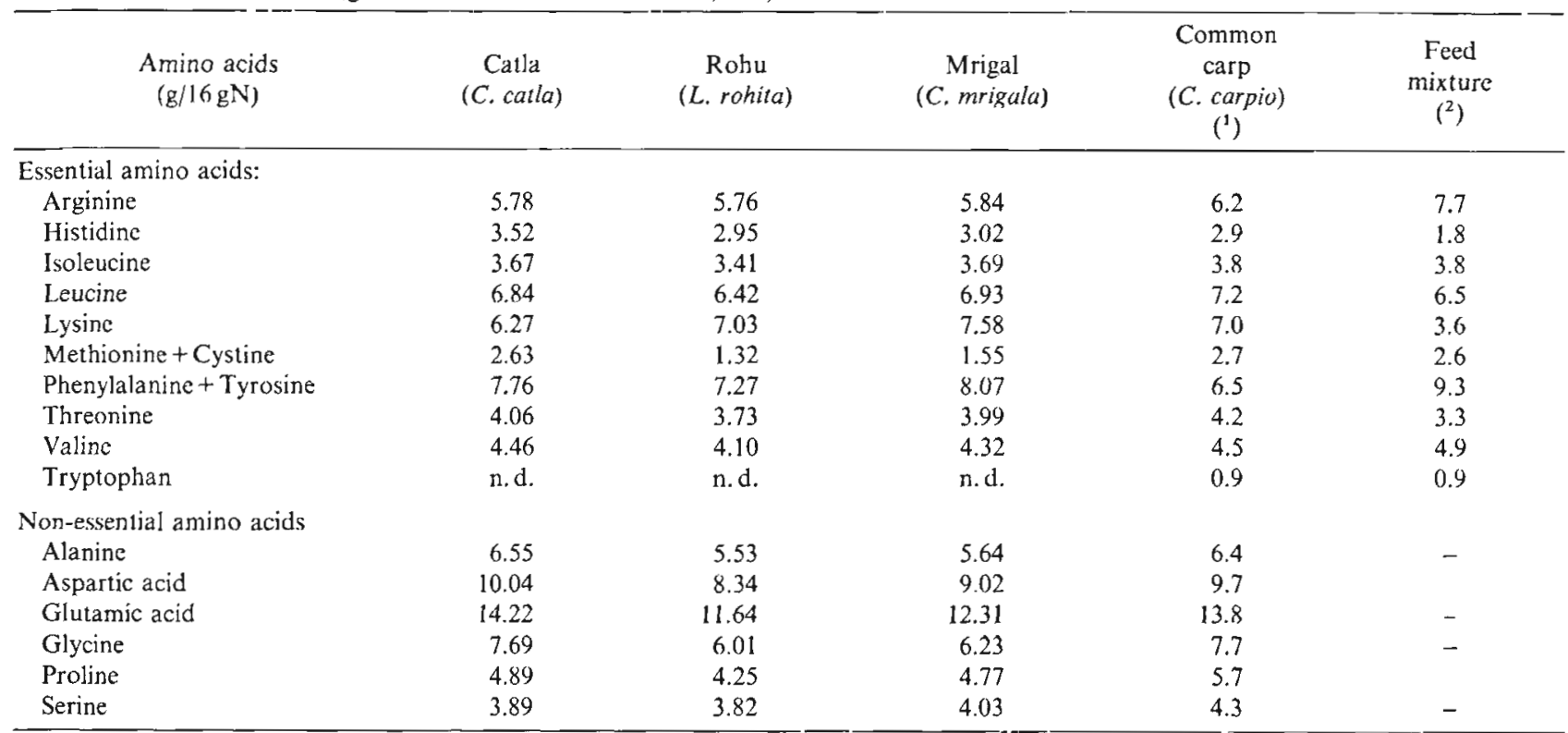

(1) Data from Schwartz and Kirschgessner, 1988.

( $\left.{ }^{2}\right)$ Recalculated from NRC, 1983.

n. $d .=$ not determined.

$110^{\circ} \mathrm{C}$ for 24 hours. The samples were analysed in a LKB 4150 alpha amino acid analyser.

From the whole-body amino acid composition, essential amino acid ratios $[\mathrm{A} / \mathrm{E}$ ratios: (cssential amino acid/sum of essential amino acids $) \times 1000]$ were computed. In the absence of data on the EAA needs of Indian major carps, the $A / E$ ratios of each of the species were subjected to regression analyses against the known EAA requirement profile of the common carp (NRC, 1983). As the estimation of methionine and of cystine in the samples was slightly affected due to oxidation, the values for these sulphur amino acids were not included in the regression analyses. The amino acid profiles were subjected to ANOVA using SAS statistical procedures (SAS, 1985).

\section{RESULTS AND DISCUSSION}

The amino acid composition of whole-body tissue of the three species are presented in table 1. The data show no major difference $(p>0.05)$ in the amino acid composition of the whole-body tissue of the fry of the three species of Indian major carp, even though the three species exhibit different feeding habits. Catla is primarily a zooplankton feeder while rohu and mrigal are herbivorous and detritus feeders respectively. There was also no significant difference $(p>0.05)$ between the amino acid composition of the three species and that of the common carp. Significant correlations were found between the EAA profiles

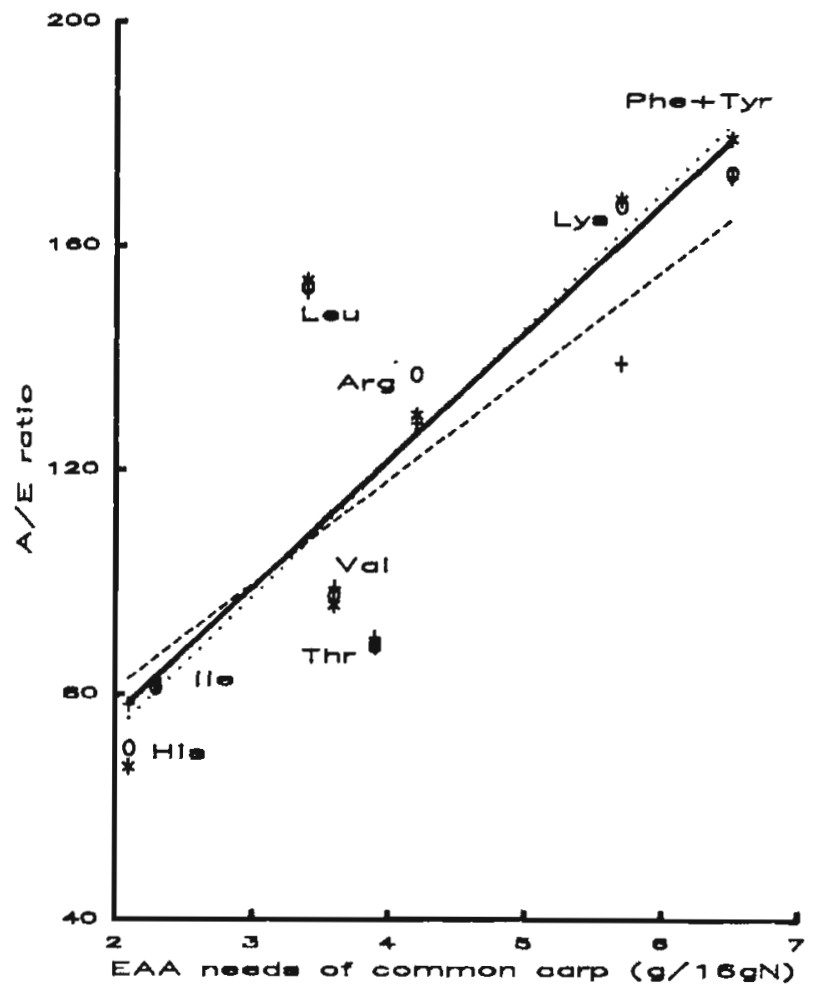

Figure 1. - Relation between the $\mathrm{A} / \mathrm{E}$ ratios in the whole body of three Indian major carps and the known EAA requirements of common carp (data from Ogino, 1980; NRC, 1983). 
of common carp and those of catla $(r=0.89)$, rohu $(r=0.95)$ and mrigal $(r=0.95)$. Gatlin (1987) and Wilson and Cowey (1985) had similarly found considerable homogeneity in the EAA profiles of several species of fish.

When comparing the whole-body amino acid composition of a given fish to that of the EAA needs of the same fish, significant correlations $(r=0.96)$ were reported for carp (Cowey and Tacon, 1983) and channel catfish (Wilson and Poe, 1985). The $\mathrm{A} / \mathrm{E}$ ratios derived from the whole-body EAA composition of the three species were plotted against the known values on the EAA needs of common carp ( fig. 1), as no specific data on the EAA needs of these three species are yet available. There was a highly significant $(p<0.01)$ correlation $(r=0.80, \quad y=0.43+0.03 \mathrm{X}, \quad r=0.85$, $y=0.33+0.03 X$ and $r=0.85, y=0.34+0.03 X$ for catla, rohu and mrigal respectively) between the two parameters suggesting that the amino acid needs of these three species might not differ much from those of the common carp.

According to Cowey and Luquet (1983), since muscle is quantitatively the major tissue of most teleosts and since the amino acid composition of fish muscle does not differ much between the species, the amino acid requirements should not also vary significantly between the species. Potential differences in the amino acid requirements may derive from variations in the relative proportions of structural proteins between species or during growth; besides, the metabolic or physiological needs for specific amino acids may also differ depending upon the physiological status of the animal (Wilson and Poe, 1985).

In table 1 are also reported some data on the EAA composition of conventional feed mixture frequently used as supplementary feed in the pond culture of these species. Calculations show that such practices of feeding these species with a mixture of groundnut oilcake and rice bran might well lead to an amino acid imbalance in the light of data on body composition of these fish. Indeed, comparison of data on the amino acid profile of such a feed to that of the whole body composition does reflect the limiting nature of lysine. Present data on the whole-body EAA profiles can serve as a valuable index for formulating amino acid test diets for Indian major carps. The patterns being similar for the three species, it should be possible to develop a common amino acid balanced diet for these carps generally farmed under composite culture systems.

\section{Acknowledgements}

The authors wish to thank Dr William Safi, Pharmacia LKB Biotechnology International AB, Sweden and Dr Nouri Baldar, Pharmacia LKB Biochrome Ltd., Cambridge, England, for their assistance in amino acid analyses of the samples and Dr S. D. Tripathi, Director CIFA, for helpful suggestions and providing working facilities.

\section{REFERENCES}

AOAC (Association of Official Analytical Chemist), 1975. Official Methods of Analysis, 12th Edit., Washington, D.C., 1094 p.

Arai S., 1981. A purified test diet for coho salmon, Oncorhynchus kisutch fry. Bull. Jpn. Soc. Sci. Fish., 47, 547-550.

Cowey C. B., P. Luquet, 1983. Physiological basis of protein requirements of fishes. Critical analysis of allowances. In: Protein Metabolism and Nutrition, R. Pion, M. Arnal, D. Bonin eds., vol. 1, INRA, Paris, p. 365384, 5-9 September.

Cowey C. B., A. G. Tacon, 1983. Fish nutrition - relevance to invertebrates. In: Biochemical and Physiological Approaches to Shellfish Nutrition, G. D. Pruder, C. J. Langdon and D. E. Conklin eds., Proc. 2nd International Conference on Aquaculturc Nutrition, Louisiana State University, Division of Continuing Education, Baton Rouge, LA, p. 13-30.

Gatlin D. M., 1987. Whole body amino acid composition and comparative aspects of amino acid nutrition of the gold fish, golden shiner and fathead minnow. Aquaculture, 60, 223-229.
Mohanty S. N., D. N. Swamy, S. D. Tripathi, 1989. Growth, nutritional indices and carcass composition of the Indian major carp fry, Catla catla, Labeo rohita and Cirrhinus mrigala fed four dictary protein levels. Aquacultura Hungarica (in press).

NRC (National Research Council), 1983. Nutrient requirements of warmwater fishes and shellfishes. National Academy Press, Washington DC, 102 p.

Ogino C., 1980. Requirements of carp and rainbow trout for essential amino acids. Bull. Jpn. Soc. Sci. Fish., 46, 171+174.

SAS Institute Inc., 1985. SAS/STAT Guide for personal computers, version 6 edition. Cary, NC, USA, 378 p.

Schwartz F. J., M. Kirchgessner, 1988. Amino acid composition of carp (Cyprinus carpio L.) with varying protein and energy supplies. Aquaculture, 72, 307-317.

Sen P. R., N. G. S. Rao, S. R. Ghosh, M. Rout, 1978. Observations on the protein and carbohydrate requirements of carps. Aquaculiure, 13, 245-255.

Singh B. N., K. K. Bhanot, 1988. Protein requirement of the fry of Catla catla (Ham.). Proc. the First Indian Fisheries Forum, M. Mohan Joseph ed., Asian Fisheries Society, Indian Branch, Mangalore, p. 77-78. 
Swamy D. N., S. N. Mohanty, S. D. Tripathi, 1988. Growth of mrigal (Cirrhinus mrigala Ham.) fingerlings fed on fishmeal based formulated diets. Proc. the First Indian Fisheries Forum, M. Mohan Joseph ed., Asian Fisheries Society, Indian Branch, Mangalore, p. 81-83.

Wilson R. P., C. B. Cowey, 1985. Amino acid composition of whole body tissue of rainbow trout and Atlantic salmon. Aquaculture, 4i, 373-376.

Wilson R. P., W. E. Poc, 1985. Relationship of whole body and egg essential amino acid patterns to amino acid requirement patterns in channel catfish, Ictulurus punctatus. Comp. Biochem. Physiol., 80B, 385-388. 